\title{
Silver eel population size and escapement in a Mediterranean lagoon: Bages-Sigean, France
}

\author{
E. Amilhat ${ }^{(1)}$, H. Farrugio( ${ }^{(1)}$, R. Lecomte-Finiger ${ }^{(2)}$, G. Simon $^{(2)}$, P. Sasal(2) \\ Received August 29, 2008 / Reçu le 29 août 2008 \\ Revised February 26, 2009 / Révisé le 26 février 2009 \\ Accepted March 2nd, 2009 / Accepté le 2 mars 2009
}

\section{ABSTRACT}

Key-words: $\quad$ Much concern has been raised about the decline in the European eel Anguillaanguilla, (Anguilla anguilla) population. European management plans for the recosilver eel, Mediterranean lagoon, markrecapture, escapement very of the stock are now in preparation, the main objective being to increase the escapement of the potential spawners (silver eels) in each basin to allow $40 \%$ of the pristine biomass to escape. However, there are relatively few studies on silver eel escapement and production, and no recent measurement of escapement in lagoons, habitats which support large silver eel sub-populations in the Mediterranean region. A markrecapture study was carried out in autumn 2007 in order to estimate the number of silver eels migrating from the Bages-Sigean lagoon in the SouthWest of France. The migrating population, mostly males between 36 and $42 \mathrm{~cm}$, was estimated to be around 1120000 eels $\left(30 \mathrm{~kg} \cdot \mathrm{ha}^{-1}\right)$. The exploitation rate by professional fishermen was around $20 \%\left(6 \mathrm{~kg} \cdot \mathrm{ha}^{-1}\right)$, leading to an escapement level of $80 \%\left(24 \mathrm{~kg} \cdot \mathrm{ha}^{-1}\right)$. The results are discussed regarding the available data in the literature on silver eel escapement.

RÉSUMÉ

Taille et échappement de la population d'anguilles argentées d'une lagune méditerranéenne : Bages-Sigean, France

\begin{abstract}
Mots-clés :
Le déclin de l'anguille européenne Anguilla anguilla est très préoccupant et chaque Anguilla anguilla, anguille argentée, lagune méditerranéenne, marquagerecapture, échappement pays européen a maintenant le devoir de préparer un plan de gestion pour la reconstitution du stock. Le principal objectif est d'assurer un taux d'échappement d'au moins $40 \%$ de la biomasse pristine des anguilles argentées (futurs géniteurs) vers leur lieu de reproduction. Cependant, très peu de recherches ont été menées sur l'estimation du stock et du taux d'échappement des anguilles argentées et aucune estimation récente du taux d'échappement n'avait encore été réalisée en Méditerranée. Cette étude de marquage-recapture a été réalisée en automne 2007 dans le but d'estimer la quantité d'anguilles argentées migrantes de la lagune de Bages-Sigean. La population migrante, principalement des mâles entre 36 et $42 \mathrm{~cm}$, a été estimée à 1120000 anguilles $\left(30 \mathrm{~kg} \cdot \mathrm{ha}^{-1}\right)$. Le taux d'exploitation par les pêcheurs professionnels évalué à $20 \%\left(6 \mathrm{~kg} \cdot \mathrm{ha}^{-1}\right)$ laisse suggérer un taux d'échappement de $80 \%\left(24 \mathrm{~kg} \cdot \mathrm{ha}^{-1}\right)$. Les résultats sont discutés au regard de la littérature disponible sur l'échappement des anguilles argentées.
\end{abstract}

(1) Laboratoire Ressources Halieutiques, IFREMER, avenue Jean Monnet, BP 171, 34203 Sète, France, elsa.amilhat@yahoo.com

(2) UMR 5244 CNRS-EPHE-UPVD, Biologie et Écologie Tropicale et Méditerranéenne, Université de Perpignan Via Domitia, 52 Avenue Paul Alduy, 66860 Perpignan Cedex, France 


\section{INTRODUCTION}

The European eel is an endangered species listed in Annex II of the Convention on International Trade in Endangered Species (CITES). All life cycle stages (glass, yellow and silver eel) have declined severely in fisheries throughout most of their distribution area (Dekker, 2003) and the stock is considered to be outside safe biological limits (ICES, 2006). The EIFAC/ICES Working Groups on Eel have advised increasing management and research on the silver eel stage, as they are the potential spawners. Following these recommendations, the EU has given each European country a mandate to write an Eel Management Plan for each of its basins representing a natural habitat for eels by the end of 2008 (Council of the European Union, 2007). The objective of each Eel Management Plan "shall be to reduce anthropogenic mortalities so as to permit with high probability the escapement to the sea of at least $40 \%$ of the silver eel biomass relative to the best estimate of escapement that would have existed if no anthropogenic influences had impacted the stock". The idea is to reconstitute the supposed panmitic stock, allowing more migrant eels to leave the European coast for the Sargasso Sea in order to reproduce. This implies a need for action on all mortality factors (fishing, obstacles to migration, contaminants, pathogens, etc.).

One key issue in meeting the $40 \%$ objective is the estimation of the pristine biomass of migrant eels. For most river basins, historical data are missing and estimates are mostly impossible.

Anguilla anguilla is largely distributed from the coast of Iceland to the North African coast (Dekker, 2003), but although important research has been carried out on the Atlantic side of the distribution area (EU programme INDICANG (ICES, 2006)), only a few studies have been conducted on the Mediterranean side. However, the French Mediterranean coast has different features to the Atlantic coast that need to be considered when promoting conservation measures. In France, glass eel fisheries are prohibited on the Mediterranean coast but yellow and silver eel fisheries, mostly localised in lagoons, represent a significant economic value. Eels represent the dominant catch from the lagoons and the total catch (estimated between 870 and 2000 tons) supports about 600 households on the French Mediterranean coast (COGEPOMI, 2006). Mediterranean lagoons are productive ecosystems and represent about 58000 ha of habitat for eels in France. One of the most likely measures used by the European Commission for rebuilding the stock would be to reduce the pressure from fisheries. This is a sensitive matter, especially because data on the exploitation rate and escapement are scarce and decisions involving catch reductions may be based on inaccurate yield estimates. Although estimation of the escapement rate is a prerequisite for rational local management, silver eel fisheries have been generally overlooked and this study represents the first field measurement of the eel spawning biomass and escapement from the French Mediterranean coast.

The aims of this study were to (1) estimate the population of migrant silver eels of a Mediterranean lagoon, Bages-Sigean; (2) estimate the pressure from fishing; and (3) evaluate silver eel escapement from the fishery. Finally, we will discuss local and global implications for the management of the eel population at the basin level.

\section{MATERIAL AND METHODS}

\section{> STUDY SITE}

Bages-Sigean lagoon (Figure 1) is situated on the northern Mediterranean coast of the Gulf of Lion (South France). It covers $38 \mathrm{~km}^{2}$, with a rather small river basin of $443 \mathrm{~km}^{2}$. Three nonpermanent rivers ("la Berre", "le Rieu" and "le Rec du Veyret") and a permanent canal, "canal de la Robine", discharge into the lagoon. The average depth of the lagoon is $1.3 \mathrm{~m}$ 


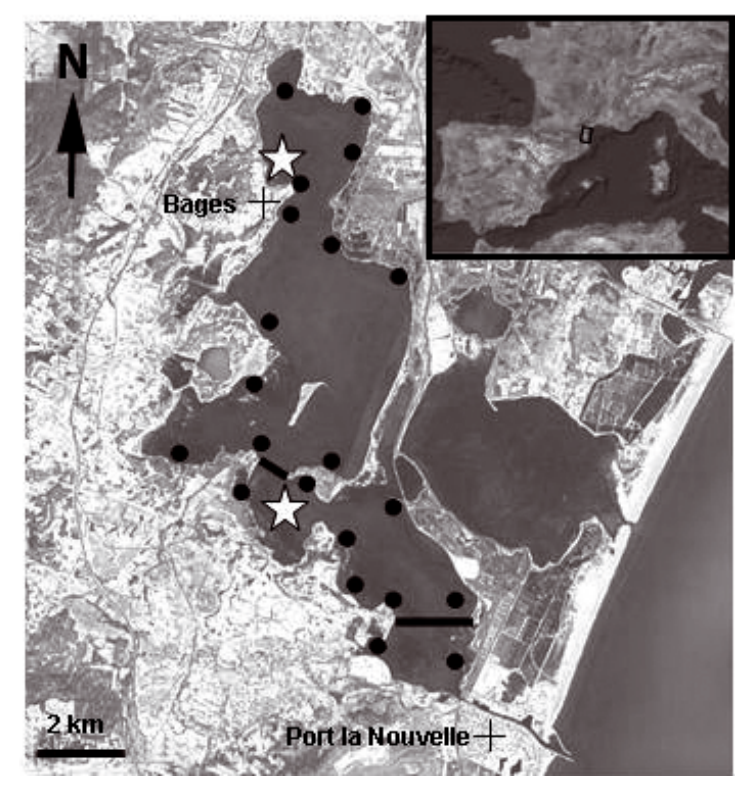

\section{Figure 1}

Location of the Bages-Sigean lagoon. Bars indicate the two net barriers and circles represent the locations of "capétchades" fishing during autumn 2007. White stars represent the two places where marked eels were released. (From Google Earth.)

\section{Figure 1}

Localisation de la lagune de Bages-Sigean. Les barres indiquent les deux barrages et les points noirs représentent les emplacements des capétchades pendant l'automne 2007. Les étoiles blanches représentent les deux sites où les anguilles marquées ont été relâchées. (D’après Google Earth.)

(2.85 m maximum) and the average salinity $32 \pm 5 \mathrm{~g} \cdot \mathrm{L}^{-1}\left(22-38 \mathrm{~g} \cdot \mathrm{L}^{-1}\right.$ range) (Parc naturel régional de la Narbonnaise en Méditerranée, 2007 data, pers. com.). The lagoon is connected to the sea via a unique opening: the channel of Port-La-Nouvelle. No sluices interfere with the migration of fish. The region is characterised by a strong wind from the North-West (tramontane), providing a good renewal of water in the lagoon.

Fishing activities on the lagoon have been recorded since the Middle Ages. Catches peaked in the 1970s and started to continuously decrease beginning in the mid-1980s (Loste and Dusserre, 1996). Eels represent more than $70 \%$ of the total catch value, and the eel fishery brought in 564 Keuros in 2005 (103 tons) and 504 Keuros in 2006 (84 tons) (Parc naturel régional de la Narbonnaise en Méditerranée, 2007). The number of fishermen, around 20, has been constant over the past 10 years (Parc naturel régional de la Narbonnaise en Méditerranée, 2007). Yellow and silver eels are targeted all year (no seasonal fishing closure), whereas glass eel fishery has always been prohibited.

\section{> COLOUR-MARKING EXPERIMENT}

A mark-recapture experiment was conducted between October and December 2007 on silver eels in the Bages-Sigean lagoon in order to estimate the population size and the number of silver eels leaving the lagoon. Annual migration of silver eels in the region occurs mainly between October and December. During that period, fishermen (19 in 2007) set up annually two net barriers at two places on the lagoon: one in the middle (over $750 \mathrm{~m}$ ) and another one in the south (over $1500 \mathrm{~m}$ ) (Figure 1). Each barrier is made of an assemblage of eel traps called "capétchades" which are assemblages of fyke-nets (passive gear). 


\section{Table I}

Number of silver eels marked in October 2007 and recaptured between October and December 2007 in Bages-Sigean lagoon. The last row indicates the total catch of silver eels in the lagoon in $\mathrm{kg}$ and the corresponding number of eels in brackets.

\section{Tableau I}

Nombre d'anguilles argentées marquées en octobre 2007 et recapturées entre octobre et décembre 2007 dans la lagune de Bages-Sigean. La dernière ligne indique la capture totale en $\mathrm{kg}$ des anguilles argentées dans la lagune et le nombre correspondant entre parenthèses.

\begin{tabular}{|l|c|c|c|c|c|}
\hline & & \multicolumn{4}{|c|}{ Recapture in numbers } \\
\hline $\begin{array}{l}\text { Release locations } \\
\text { (date) }\end{array}$ & $\begin{array}{c}\text { Total no. } \\
\text { tagged }\end{array}$ & Oct. & Nov. & Dec. & $\begin{array}{c}\text { Total catch } \\
(\%)\end{array}$ \\
\hline $\begin{array}{l}\text { Northern shore } \\
\text { (15 Oct. 2007) }\end{array}$ & 537 & 14 & 111 & 0 & $\begin{array}{c}125 \\
(23 \%)\end{array}$ \\
\hline $\begin{array}{l}\text { Southern shore } \\
\text { (29 Oct. 2007) }\end{array}$ & 505 & 30 & 55 & 0 & $\begin{array}{c}85 \\
(17 \%)\end{array}$ \\
\hline $\begin{array}{c}\text { Capture in kg } \\
\text { (Number) }\end{array}$ & $\begin{array}{c}5999 \\
(58814)\end{array}$ & $\begin{array}{c}16473 \\
(161500)\end{array}$ & $\begin{array}{c}663 \\
(6500)\end{array}$ & $\begin{array}{c}23135 \\
(226814)\end{array}$ \\
\hline
\end{tabular}

The lagoon is naturally separated into two pools by the island "de l'Aute", leaving a small passage of about $750 \mathrm{~m}$ (where fishermen set up the north barrier nets). The two parts of the lagoon have different environmental conditions that could lead to different eel subpopulations. The north pool is deeper and it receives most of the freshwater run-off (mean salinity: $27.6 \pm 4.0 \mathrm{~g} \cdot \mathrm{L}^{-1}$ ) and therefore pollution. The south pool has a tendency to fill up, is directly connected to the sea (salinity: $35.4 \pm 3.0 \mathrm{~g} \cdot \mathrm{L}^{-1}$ ) and its water is more frequently renewed (IFREMER, 2008). The first capture on the north barrier usually happens before that on the south barrier and fishermen differentiate between the eels coming from the north (lighter colour) and the south (Loste and Dusserre, 1996). Therefore, in order to have a better representation of the entire eel stock, we decided to mark two batches of silver eels, one from each part of the lagoon (Table I). As soon as silver eels started their migration in October (induced by special environmental conditions, principally strong wind and low temperatures), they were caught in the net barriers by the fishermen, and a sample from each barrier was colour-marked (north code: 1 red dot or 2 green dots, south code: 1 green dot).

Silver stage was determined based on the combination of two macroscopic criteria: a differentiated lateral line (presence of black corpuscles) and a contrasting colour (dark dorsal surface and a white ventral surface). Although the ocular hypertrophy values $(\mathrm{Ol}>6.5)$ should be considered as a criterion for silver eel determination (Acou et al., 2005) it was not calculated in the field for logistic reasons. However, Durif et al. (2005) showed that the increase in the ocular diameter appears before the pigmentation change, therefore we considered it valid to use only the two criteria.

Silver eels were marked with acrylic paint ("Van Gogh" permanent green light 618) and ink ("Magic Color" process magenta MC 620). These two colours have previously been successfully tested on silver eels in mark-recapture experiments in the river Loire (Boury et al., unpublished data). Paint or ink was injected inside the base of the dorsal fin using syringes. Mortality induced by the marking procedure and mark visibility were measured in a controlled environment over a period of six months. No marking-induced mortality or mark visibility loss was observed (Amilhat et al., unpublished data). This technique was preferred to external tags which tend to be lost during capture or when eels rub against the nets (where they may stay a few days). Also, colour marks should not affect the catchability of the eels as only passive gear is used. Each marked eel was measured (total length to the nearest $\mathrm{mm}$ ), weighed (to the nearest g) and released the same day. 


\section{> SILVER EEL STOCK, EXPLOITATION RATES AND ESCAPEMENT ESTIMATIONS}

Eels (marked and non-marked) were captured as part of normal fishing activities by the professional fishermen. All the eels captured were removed from the system. Figure 1 shows the positions of the capétchades between October and December 2007. Fishermen scattered nets throughout the lagoon in addition to the two net barriers. The results are calculated from captures made from all the capétchades (barrier and non-barrier nets). Fishermen must declare the total weight of their captures using log-books. The number and characteristics of colour codes of recaptured marked eels were recorded daily by fishermen. Group meetings with fishermen and information campaigns (advertised using posters displayed in strategic places and in newspapers) were carried out during the study period.

In our experiment, marks and recoveries took place over a number of strata. Silver eels were marked in two locations on two different dates (two initial strata), and recoveries took place over the migration period from October to December (three final strata corresponding to different intensity in migration). Population size was estimated from two estimators commonly used and adapted to a stratified experiment: the Darroch reformulated by Plante (1990), and pooled Petersen (Seber, 1982) estimators. This method was previously successfully used by Caron et al. (2003) to estimate silver American eel population stock and escapement in the St. Lawrence. It is based on the number of recaptured tagged silver eels among the total silver eels caught by strata. The pooled Petersen consists of pooling data over the strata. It gives the most precise estimate of population size but can be biased if tagging or recovery probabilities are heterogeneous (Arnason et al., 1996). To tackle this problem, the ML Darroch estimates stratify the tagging and the recovery probabilities. The two estimators are based on maximum likelihood theory. Mathematical formulae are found in Seber (1982, Chapter 11). Two estimates are used with a view to increasing the validity of the results. The calculations were performed using the SPAS software (Stratified Population Analysis System) from Arnason et al. (1996). Confidence intervals $(\mathrm{Cl})$ were calculated for $\alpha=0.05$. Our data met the assumptions of these methods. The assumptions are an extended version of those of the simple Petersen experiment (Arnason et al., 1996): (1) Closure: eels from the capture strata have a non-zero probability of recovery in one of the final strata. (2) No tag loss: eels retain their mark and are correctly identified as marked or unmarked. (3) Equal catchability: all eels (marked or unmarked) in a given final stratum have the same probability of being sampled; and (4) All marked eels released in a given initial stratum have the same probability distribution of movement to the final strata.

Total catch in weight was converted into numbers of eels using the individual median weights obtained from the sampling of the marked silver eels. The exploitation rate was obtained using the total catch estimate divided by the pooled Petersen estimate. Escapement of the migrant eels from the fishery was calculated by subtracting the annual catch from the population estimate.

\section{RESULTS}

\section{> SILVER EEL POPULATION}

A total of 1042 silver eels was marked on two occasions in October 2007 (Table I). Sizes ranged from 230 to $812 \mathrm{~mm}$ and the dominant size classes were 380,400 and $420 \mathrm{~mm}$ (ranging from 361 to $420 \mathrm{~mm}$ ) (Figure 2). Ninety-seven per cent of the eels sampled were inferior to $44 \mathrm{~cm}$, sizes dominated by males (Tesch, 2003). The median length of the eels was $390 \mathrm{~mm}$ and the median weight $102 \mathrm{~g}$ (50-1228 g, $n=1042)$. Silver eels captured on the north barrier measured and weighed less than those from the south barrier (Kolmogorov-Smirnov; $P<0.05)$. 


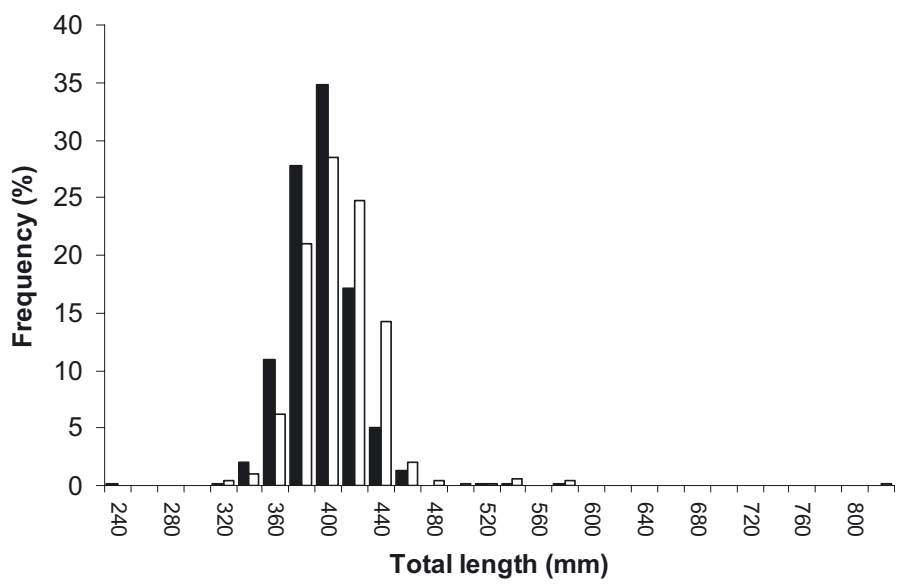

\section{Figure 2}

Length frequency histogram of silver eels captured on the north nets barrier (solid bars, $n=$ 537) and on the south nets barrier (open bars, $n=505$ ).

\section{Figure 2}

Distribution des fréquences de tailles des anguilles argentées capturées sur le barrage nord (barres noires, $n=537$ ) et sur le barrage sud (barres blanches, $n=505$ ).

\section{Table II}

Silver eel population size estimates $(N)$, exploitation rate $(E)$ and escapement rate (\%). The $95 \%$ confidence intervals are indicated in brackets.

Tableau II

Estimateurs de la taille de la population d'anguilles argentées $(N)$, taux d'exploitation $(E)$ et taux d'échappement (\%). L'intervalle de confiance à $95 \%$ est indiqué entre crochets.

\begin{tabular}{|l|c|c|c|}
\hline Method & $N$ & $E(\%)$ & Escapement rate (\%) \\
\hline ML Darroch & 1259509 & 18 & 82 \\
& {$[1021426-1497593]$} & {$[15-22.2]$} & {$[77.8-84.9]$} \\
\hline Pooled Petersen & 1120112 & 20.2 & 79.8 \\
& {$[985586-1254640]$} & {$[18.1-23]$} & {$[77-81.9]$} \\
\hline
\end{tabular}

\section{> POTENTIAL SPAWNER POPULATION SIZE, EXPLOITATION RATE AND ESCAPEMENT ESTIMATES}

Among the 1042 silver eels marked, 210 were recaptured (20\%) by the end of the migration period in December (Table I). The recapture rate for eels released from the north shore and from the south shore were $23 \%$ and $17 \%$, respectively, and not significantly different $\left(\chi^{2}=6.7\right.$, $\mathrm{df}=1, P>0.01)$. The total capture of silver eels in 2007 was $23135 \mathrm{~kg}(1218 \mathrm{~kg} /$ fisherman on average). The peak catch occurred in November and was $16473 \mathrm{~kg}$. The captures represent 226814 silver eels in total. The estimated silver eel stock ranged between 1120112 and 1259509 individuals (Table II), corresponding to a biomass between 30 and $33.8 \mathrm{~kg} \cdot \mathrm{ha}^{-1}$ (114.251 to 128.470 tons). The results are similar for the different methods of estimation. The exploitation rate was estimated at between 18 and $20.2 \%\left(6 \mathrm{~kg} \cdot \mathrm{ha}^{-1}\right)$. Consequently, the silver eels that escaped from the fishery comprised between 79.8 and $82 \%\left(24-27.8 \mathrm{~kg} \cdot \mathrm{ha}^{-1}\right)$ of the stock in 2007 (Table II). 


\section{DISCUSSION}

Although European management plans require information on the pristine biomass and escapement levels of silver eels, very few data are available (Table III). We observed that the biomass, escapement and yield of silver eels in the lagoon systems were generally higher than those of river systems. The estimated silver eel production in Bages-Sigean lagoon $\left(30 \mathrm{~kg} \cdot \mathrm{ha}^{-1}\right)$ is high compared with the data available in the literature (Table III): $1.5-20 \mathrm{~kg} \cdot \mathrm{ha}^{-1}$ in lagoons and $0.003-6.9 \mathrm{~kg} \cdot \mathrm{ha}^{-1}$ in freshwater systems, but still inferior to the extremely productive Frémur catchment, estimated at from 17-50 kg.ha- ${ }^{-1}$ (Feunteun et al., 2000; Acou et al., 2009). Lagoons are in general more productive than freshwater ecosystems, providing higher growth rates (Panfili and Ximenes, 1994; Acou et al., 2003). Our estimate is surprisingly superior to the pristine biomass proxies estimated in Camargue $\left(25 \mathrm{~kg} \cdot \mathrm{ha}^{-1}\right.$, Bevacqua, pers. com.) and observed in Italy in the $70 \mathrm{~s}\left(20 \mathrm{~kg} \cdot \mathrm{ha}^{-1}\right.$, Rossi (1979)). However, environmental conditions, such as the level of glass eel recruitment, differ across Mediterranean lagoons (Crivelli, pers. com.) which may cause significant variability in biomass. Bages-Sigean lagoon benefits from a direct access to the sea (no obstacles) unlike the Camargue lagoons.

Bages-Sigean lagoon produced mostly males $(97 \%<44 \mathrm{~cm})$. The male dominance reflects the eel densities in the catchment (usually $>500-1000$ eels $\cdot$ ha $^{-1}$ when dominated by males) and is linked to environmental conditions such as level of recruitment, fishing level and possibly trophic composition (Robinet et al., 2007; Acou et al., 2009). Large females with a high fecundity are generally considered more crucial for the spawning stock. However, the sex ratio of the spawners in the Sargasso Sea is still unknown and the consequences of a skewed sex ratio on the population remain controversial. Data available before the drop in the population suggested that the sex ratio was skewed in favour of males (ICES, 2007). Lagoons could be crucial habitats for European eel conservation, having the role of male reservoirs. They produce a high number of males in a reduced time. The silver stage is reached earlier in lagoons compared with river/estuarine systems (Acou et al., 2003; Robinet et al., 2007). The high turnover of the population (shorter generation time for males) could minimise the impact of environmental factors, such as punctual degradation of the habitat.

Potential spawners in Bages-Sigean were estimated to be around 1120000 eels, corresponding to biomass of around $24 \mathrm{~kg} \cdot \mathrm{ha}^{-1}$, the highest value estimated until now (Table III). Escapement was high, estimated at $80 \%$. This result may be surprising, considering the high fishing pressure exerted by the two barriers. However, the net barriers are not completely hermetic to eel passage. Also, eels escape easily above the nets when the water level rises in the lagoon, as happens often during the migration season (fishermen, pers. com.). However, possible bias encountered by mark-recapture experiments, especially those based on commercial fishery, have to be considered. The main sources of error are (1) the underestimation of the number of marked eels recaptured, (2) the underestimation of the fishing mortality (fishermen may have under-declared their catches) and (3) inaccuracy of the assumption that all the marked eels migrated on the year of the experiment. All these biases will result in an overestimation of the biomass and therefore of the escapement rate. However, we think source (2) is negligible, as one of the reasons we decided to work on this lagoon was the high participation and motivation of the fishermen to work with us. Bias (3) we also think is negligible because Bages-Sigean lagoon has an open access to the sea. Although in large rivers the pre-migrant eels may take several years before reaching the estuary (Feunteun et al., 2000; Rosell et al., 2005), a one-to-one relation between pre-migrant eels and silver migrant eels is assumed in small catchments (Acou et al., in press). Moreover, no marked eels were recaptured by the fishermen the following year, which supports the idea that all eels attempted to migrate. The main source of error would come from (1) unreported or unobserved marks, either because fishermen want to minimise the perceived effect of the fishery, or because some marks may be missed during the days of high catches. In order to simulate such a case, we calculated the mean return rate per $\mathrm{kg}$ from the fishermen believed to count the marks most accurately and adjusted to the total catch. We estimated 156 additional marks, which resulted in a lower biomass: $17.3 \mathrm{~kg} \cdot \mathrm{ha}^{-1}$, a higher exploitation 


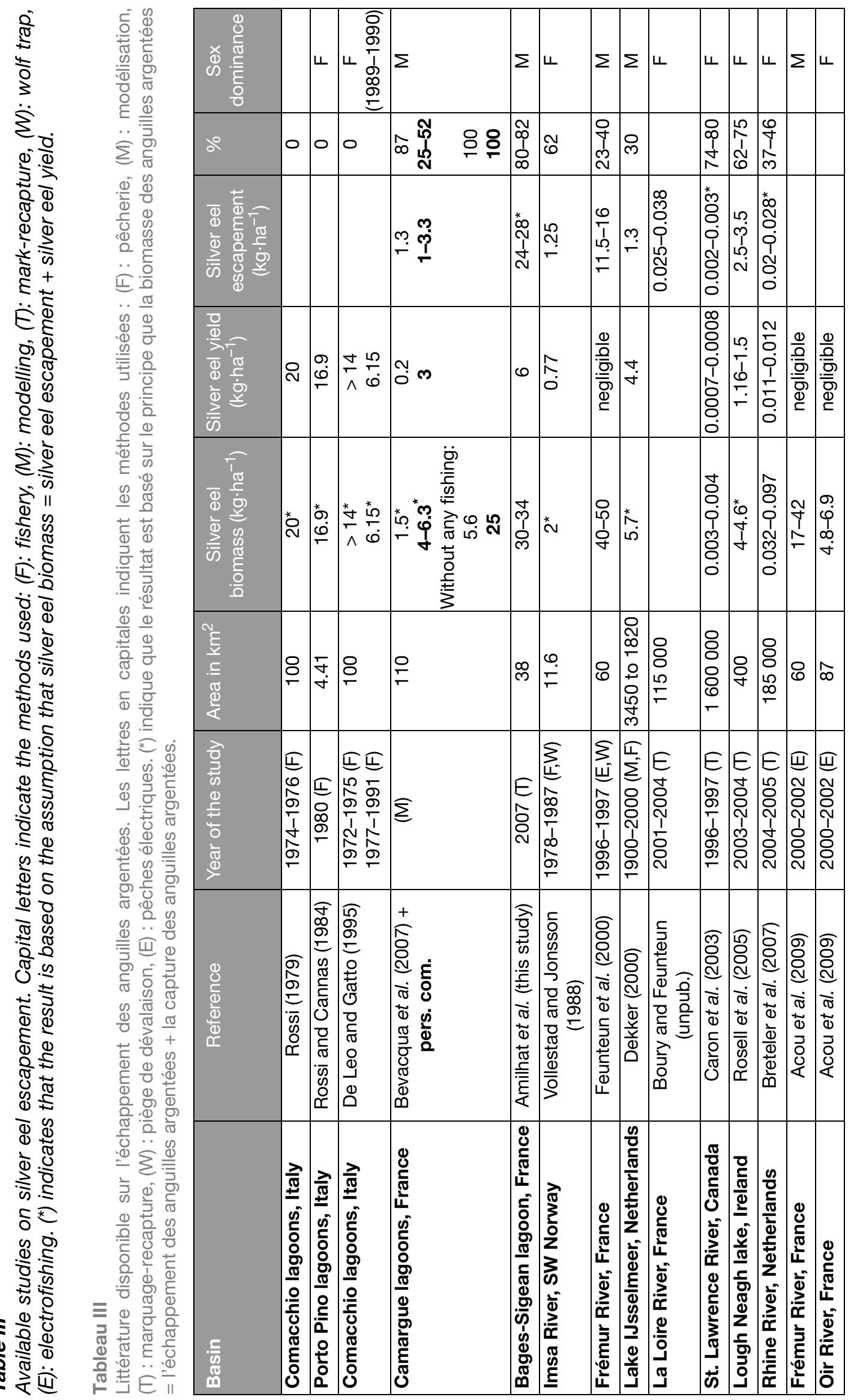


rate: $35 \%$ and an escapement rate of $65 \%$ (Cl: $62-68 \%)$. Although lower, the escapement rate is still quite high. A previous study on the same lagoon in autumn 2006 supports our results (Farrugio et al., 2007). This study was carried out in order to test whether French legislation prohibiting the closure of more than two-thirds of a lagoon entrance allowed sufficient eel escapement. Two barriers made from "capétchades" were placed in the north of the lagoon. The first was two-thirds open and the second completely closed in order to estimate the proportion of eels going through the first barrier. Based on total weight difference between total captures in each barrier, it was inferred that the first barrier let $59 \%$ of the biomass escape. This rate could be adjusted with data from our mark-recapture experiment, where 24 eels out of the 537 marked (4.5\%) passed through the first full barrier to be recaptured in the second one. Fishermen have observed that eels migrate mostly on the edges of the lagoon. It is therefore possible to assume the escapement in 2006 to be around $63.5 \%$ (59\% $+4.5 \%)$.

The only historical estimate available in lagoon systems is for the Comacchio lagoons in Italy, where in the 70s, only silver eels were fished (i.e. there were no direct effects on younger stages in the lagoon). Fishermen used a series of V-shaped screens (called lavorieri) at the only outlet of the lagoon (De Leo and Gatto, 1995). These traps were designed to capture the whole migrating stock. A maximum capture of $20.5 \mathrm{~kg} \cdot \mathrm{ha}^{-1}$ was recorded in 1974 . The oldest data on silver eel captures retrieved for Bages-Sigean lagoon were recorded in 1985 and 1986, with 2 and $12 \mathrm{~kg} \cdot \mathrm{ha}^{-1}$ yielded, respectively (Loste and Dusserre, 1996). A survey carried out between 1985 and 1995 (Loste and Dusserre, 1996) showed that the annual captures of silver and yellow eels were closely related. The total silver eel catch in 2007 (this study) represented half of the catch recorded in 1986, a year corresponding to around the start of the deep decline in the European eel stock (ICES, 2008). As the fishing effort has remained relatively constant since 1986 (Loste and Dusserre, 1996), this would mean that about $50 \%$ of the biomass may have decreased from 1986-2007. Silver eel biomass in 1986 would be equal to two times the one we estimated in $2007\left(30 \mathrm{~kg} \cdot \mathrm{ha}^{-1 *} 2=60 \mathrm{~kg} \cdot \mathrm{ha}^{-1}\right)$. If we hypothesised that the biomass recorded in 1986 is close to the pristine one, we could estimate the escapement necessary to meet the Eel Recovery Plan of the EU. Based on the minimum escapement of $40 \%$ proposed by the EU, $24 \mathrm{~kg} \cdot \mathrm{ha}^{-1}\left(40 \%\right.$ of $\left.60 \mathrm{~kg} \cdot \mathrm{ha}^{-1}\right)$ would be the minimum escapement required to meet the regulation. In 2007, we estimated the escapement to be around $24 \mathrm{~kg} \cdot \mathrm{ha}^{-1}$ in the Bages-Sigean lagoon, which is at the limit of this regulation. However, if we consider unreported marks as explained above, the escapement would be below the EU limit. Bevacqua et al. (2007 and pers. com.) estimated the actual escapement of the eel population of the Camargue lagoons to be between 25 and $87 \%$. However, when compared with their proxy of the pristine biomass (estimate of the biomass without any fishing activities), the estimate drops to $4-23 \%$, far below the $40 \%$ limit. Management decisions will, therefore, be very dependent on the estimation of the pristine biomass. The escapement level in the Bages-Sigean lagoon is close to the threshold limit, which highlights the need for local management measures. Achieving $40 \%$ escapement would probably have minor consequences for Bages-Sigean's fishermen because management decisions are taken at the "eel river basin" level (grouping all the French continental river basins flowing toward the Mediterranean Sea into one unit of management). However, each river basin has particularities, and even if they look similar in their sizes and proximity they can have completely different breeding potentials (Acou et al., 2009). River basins need to be considered at the local level, especially when they support significant socio-economic activity. In order to sustain fishery activity, different management scenarios such as seasonal closure of the fishery or change in mesh size should be tested to identify possible ways to optimise yield under conservation limits (Bevacqua et al., 2007).

The results obtained in this study are important baseline data for Bages-Sigean lagoon and the method may be used to estimate escapement in other lagoons. However, extrapolation to other lagoons should consider local environment conditions and eel population parameters (Acou et al., 2009). The escapement level within the same lagoon may change from year to year depending on environmental conditions and the age structure of the other stages in the eel population, including glass eels and yellow eels. We realise that our study 
constitutes the results of one year and that further research is needed to validate the escapement tendency. It is necessary to monitor escapement at regular time intervals. Direct estimates of escapement are not possible for all lagoons. Another promising method to predict escapement is to use population dynamic models based on population parameters such as growth, sex ratio and density-dependent mortality (De Leo and Gatto, 1995; Bevacqua et al., 2007). The advantage of using such population dynamic models is the potential to test the effect of a large number of local conservation measures. However, direct estimations of escapement are still necessary to validate the models.

Apart from increasing the number of migrant eels, it is important to address potential spawner quality issues. Recent studies have indicated that infection with the parasitic swim bladder nematode Anguillicola crassus (Palstra et al., 2007) and EVEX eel rhabdovirus (van Ginneken et al., 2005), and contamination with dioxin-like PCBs (Palstra et al., 2006) and with cadmium (Pierron et al., 2008) could be responsible for migration or reproduction impairment. It is therefore essential to combine research on escapement with studies of migrant eel quality. In order to reflect the correct breeding potential in terms of the number of eels able to successfully reach the Sargasso Sea and reproduce, basin-level models should consider the effect of migrant eel quality reduction on the escapement potential (Robinet et al., 2007). The EU objective of increasing the number of migrant eels has meaning only if they have a chance to reproduce successfully.

\section{ACKNOWLEDGEMENTS}

The authors are indebted to the fishermen from Bages-Sigean lagoon who participated actively in the research project, especially Didier Peyrille and Olivier Cabos, who provided the silver eels to be marked. Also, they are very grateful to the local fishing committee for their support and help in arranging meetings with the fishermen. Thanks also to Séverine Paris, Pablo Saenzagudelo and Florence Cartault for their help on the tagging days. Thanks to Karine Dusserre from the Parc naturel régional de la Narbonnaise for providing environmental data. Thanks to Penny Hancock, Michael Blouin and Edouard Jobet for the improvements they made to the manuscript. Gérome Micheau and Richard Aguirre are thanked for their participation in the project. We also acknowledge the constructive comments on the manuscript of Daniele Bevacqua and an anonymous reviewer. The research was supported by IFREMER, France. Pierre Sasal and Raymonde Lecomte-Finiger were partly financed by the CE-Eeliad $n^{\circ} 212133$ project.

\section{REFERENCES}

Acou A., Lefebvre F., Contournet P., Poizat G., Panfili J. and Crivelli A.-J., 2003. Silvering of female eels (Anguilla anguilla) in two sub-populations of the Rhône Delta. Bull. Fr. Pêche. Piscic., 368, 55-68.

Acou A., Boury P., Laffaille P., Crivelli A.J. and Feunteun E., 2005. Towards a standardized characterization of the potentially migrating silver European eel (Anguilla anguilla, L.). Arch. Hydrobiol., 164, 237-255.

Acou A., Gabriel G., Laffaille P. and Feunteun E., 2009. Differential production and condition indices of premigrant eels in two small Atlantic coastal catchments of France. In: Casselman J.M. and Cairns D.K. (eds.), Eels at the edge: science, status, and conservation concerns, Amer. Fish. Soc. Symp., 58, Bethesda, Maryland, 157-174.

Arnason A.N., Kirby C.W., Schwarz C.J. and Irvine J.R., 1996. Computer analysis of data from stratified mark-recovery experiments from estimation of salmon escapements and other populations. Canadian Technical Report of Fisheries and Aquatic Sciences, 2106, 37 p.

Bevacqua D., Melià P., Crivelli A.J., De Leo G.A. and Gatto M., 2007. Multi-objective assessment of conservation measures for the European eel (Anguilla anguilla): an application to the Camargue lagoons. ICES J. Mar. Sci., 64, 1483-1490.

Breteler J.K., Vriese T., Borcherding J., Breukelaar A., Jorgensen L., Staas S., de Laak G. and Ingendahl D., 2007. Assessment of population size and migration routes of silver eel in the river Rhine based on a 2-year combined mark-recapture and telemetry study. ICES J. Mar. Sci., 64, 1450-1456. 
Caron F., Verreault G. and Rochard E., 2003. Estimation of the population size, exploitation rate, and escapement of silver-phase American eels in the St. Lawrence watershed. Am. Fish. Soc. Symp., 33, 235-242.

COGEPOMI, 2006. Programme de gestion de l'anguille sur les lagunes méditerranéennes 2006-2008, Direction Régionale de l'Environnement Rhône-Alpes Bassin Rhône - Méditerranée, Lyon, France, $6 \mathrm{p}$.

Council of the European Union, 2007. Council Regulation (EC) No 1100/2007 of 18 September 2007 establishing measures for the recovery of the stock of European eel, Brussels, $7 \mathrm{p}$.

De Leo G.A. and Gatto M., 1995. A size and age-structured model of the European eel (Anguilla anguilla L.). Can. J. Fish. Aquat. Sci., 52, 1351-1367.

Dekker W., 2000. Impact of yellow eel exploitation on spawner production in Lake IJsselmeer, the Netherlands. Dana, 12, 25-40.

Dekker W., 2003. On the distribution of the European eel (Anguilla anguilla) and its fisheries. Can. J. Fish. Aquat. Sci., 60, 787-799.

Durif C., Dufour S. and Elie P., 2005. The silvering process of the European eel: a new classification from the yellow resident stage to the silver migrating stage. J. Fish. Biol., 66, 1025-1043.

Farrugio H., Peyrille D. and Cabos O., 2007. Mesure de l'efficacité de la réglementation française de la pêche à l'anguille dans la lagune méditerranéenne de Bages-Sigean, IFREMER, Laboratoire Ressources Halieutiques, Sète, HMT/RH Sète/07-01, 9 p.

Feunteun E., Acou A., Laffaille P. and Legault A., 2000. European eel (Anguilla anguilla): prediction of spawner escapement from continental population parameters. Can. J. Fish. Aquat. Sci., 57, 1627-1635.

ICES, 2006. Report of the Joint EIFAC/ICES Working Group on Eels (WGEEL), 23-27 January 2006, Rome, Italy, ICES CM 2006/ACFM:16, 352 p.

ICES, 2007. Report of the Joint EIFAC/ICES Working Group on Eels (WGEEL), 3-7 September 2007, Bordeaux, France, ICES CM 2007/ACFM:23, 534 p.

ICES, 2008. Report of the Joint EIFAC/ICES Working Group on Eels (WGEEL), 3-9 September 2008, Leuven, Belgium, ICES CM 2008/ACOM:15, 212 p.

IFREMER, 2008. Réseau de Suivi Lagunaire du Languedoc-Roussillon : Bilan des résultats 2007, Rapport RSL-08/2008, 363 p.

Loste C. and Dusserre K., 1996. La pêche sur l'étang de Bages-Sigean. Évolutions de 1985 à 1995 , CEPRALMAR Report, Montpellier, $100 \mathrm{p}$.

Palstra A.P., van Ginneken V.J.T., Murk A.J. and van den Thillart G., 2006. Are dioxin-like contaminants responsible for the eel (Anguilla anguilla) drama? Naturwissenschaften, 93, 145-148.

Palstra A.P., Heppener D.F.M., van Ginneken V.J.T., Szekely C. and van den Thillart G., 2007. Swimming performance of silver eels is severely impaired by the swim-bladder parasite Anguillicola crassus. J. Exp. Mar. Biol. Ecol., 352, 244-256.

Panfili J. and Ximenes M.C., 1994. Évaluation de l'âge et de la croissance de l'anguille européenne (Anguilla anguilla L.) en milieu continental : méthodologies, validation, application en Méditerranée et comparaisons en Europe. Bull. Fr. Pêche Piscic., 335, 43-66.

Parc naturel régional de la Narbonnaise en Méditerranée, 2007. Tableau de bord du contrat pour les étangs du Narbonnais, $43 \mathrm{p}$.

Pierron F., Baudrimont M., Dufour S., Elie P., Bossy A., Baloche S., Mesmer-Dudons N., Gonzalez P., Bourdineaud J.P. and Massabuau J.C., 2008. How cadmium could compromise the completion of the European eel's reproductive migration. Environ. Sci. Technol., 42, 4607-4612.

Plante N., 1990. Estimation de la taille d'une population animale à l'aide d'un modèle de capturerecapture avec stratification, Masters Thesis, Université Laval, Quebec, Canada.

Robinet T., Acou A., Boury P. and Feunteun E., 2007. Concepts for characterizing spawning biomass of the European eel (Anguilla anguilla) in catchments. Vie Milieu, 57, 201-211.

Rosell R., Evans D. and Allen M., 2005. The eel fishery in Lough Neagh, Northern Ireland - an example of sustainable management? Fisheries Manag. Ecol., 12, 377-385.

Rossi R., 1979. An estimate of the production of silver eel in the Valli di Comacchio (Po Delta) during 1974-1976. Boll. Zool., 46, 217-223.

Rossi R. and Cannas A., 1984. Eel Fishing Management in a Hypersaline Lagoon of Southern Sardinia. Fish. Res., 2, 285-298.

Seber G.A.F., 1982. The estimation of animal abundance and related parameters, 2nd edition, Charles Griffen, London, UK, $653 \mathrm{p}$.

Tesch F.W., 2003. The Eel, 5th edition, Blackwell Scientific Publications, Oxford, UK, 408 p.

van Ginneken V., Ballieux B., Willemze R., Coldenhoff K., Lentjes E., Antonissen E., Haenen O. and van den Thillart G., 2005. Hematology patterns of migrating European eels and the role of EVEX virus. Comp. Biochem. Physiol. C-Toxicol. Pharmacol., 140, 97-102.

Vollestad L.A. and Jonsson B., 1988. A 13-year study of the population-dynamics and growth of the European eel Anguilla anguilla in a Norwegian river: evidence for density-dependent mortality, and development of a model for predicting yield. J. Anim. Ecol., 57, 983-997. 